DOI : https://doi.org/10.31539/jomb.v1i1.602

\title{
ANALISIS STORE ENVIRONMENT DAN EMOSI POSITIF TERHADAP IMPULSE BUYING
}

\author{
Ayi Muhyidin ${ }^{1}$, Erry Sunarya ${ }^{2}$, Asep M. Ramdan ${ }^{3}$ \\ Universitas Muhammadiyah Sukabumi ${ }^{1,2,3}$ \\ Email: amuhyidin26@gmail.com ${ }^{1}$
}

\begin{abstract}
ABSTRAK
Tujuan penelitian ini adalah untuk menganalisis pengaruh store environment dan emosi positif terhadap impulse buying pada cafe. Metode yang digunakan dalam penelitian ini adalah menggunakan jenis probabilitas sampling yaitu simple random sampling dengan melakukan penyebaran kuesioner sebanyak 100 kepada konsumen. Teknik analisis yang digunakan adlah teknik analisis regresi berganda, termasuk uji koefisien determinasi, koefisien korelasi ganda, uji secara simultan (uji F), dan uji secara parsial (uji T). Hasil penelitian uji koefisien determinasi dilihat dari nilai (Adjusted $\mathrm{R}^{2}$ ) sebesar 0,425 dapat diartikan bahwa pengaruh Store Environment dan Emosi Positif terhadap Impulse Buying adalah sebesar 42,5\%. Sisanya 57,5\% dipengaruhi oleh faktor-faktor lain diluar penelitian ini. Berdasarkan uji koefisien korelasi ganda dilihat dari nilai $\mathrm{R}$ sebesar 0,661, menunjukan bahwa terjadi hubungan yang kuat antara kualitas makanan dan perceived value dengan kepuasan konsumen. Berdasarkan uji $\mathrm{F}$ nilai probabilitas sig. $0,000<0,10$, yang berarti bahwa secara bersama-sama Store Environment $\left(\mathrm{X}_{1}\right)$ dan Emosi Positif $\left(\mathrm{X}_{2}\right)$ berpengaruh secara signifikan terhadap Impulse Buying (Y). Simpulan, berdasarkan uji T menunjukan bahwa Store Environment $\left(\mathrm{X}_{1}\right)$ berpengaruh signifikan terhadap Impulse Buying $(\mathrm{Y})$, Emosi Positif $\left(\mathrm{X}_{2}\right)$ berpengaruh signifikan terhadap Impulse Buying (Y).
\end{abstract}

Kata Kunci : Store Environment, Emosi Positif, Impulse Buying

\section{ABSTRACT}

The purpose of this study was to analysis the effect of store environment and positive emotions on impulse buying in the cafe. The method used in this study is the use the type of probability sampling includes in the simple random sampling. The sample used in this research was 100 respondents and data collection methods using a questionnaire. The analysis technique using validity test, reliability test, multiple linear regression analysis, including test coefficient of determination, multiple correlation coefficient, simultaneous test ( $F$ test), and partial test (T test). The results of the test coefficient of determination seen from value (Adjusted $R^{2}$ ) of 0,425 can be interpreted that the effect of Store Environment and Positive Emotions on Impulse Buying is 42,5\%. The remaining 57,5\% is influenced by other factors not explained in this study. Based on the multiple correlation coefficient test seen from the $R$ value of 0.661 , it shows that there is a strong relationship between store environment and positive emotions with impulse buying. Based on the $F$ test the probability value sig. 0,000<0,10, which means that together Store Environment $\left(X_{1}\right)$ and Positive Emotions $\left(X_{2}\right)$ significantly influence Impulse Buying $(Y)$. Conclusion, based on the t test showing Store Environment $\left(X_{1}\right)$ has 
a significant effect on Impulse Buying (Y), Positive Emotions $\left(X_{2}\right)$ has a significant effect on Impulse Buying ( $Y$ ).

Keyword : Store Environment, Positive Emotions, Consumer Satisfaction

\section{PENDAHULUAN}

Topik penelitian mengenai impulse buying peneliti mengkaji, selama 10 tahun terakhir. Berdasarkan data (Kharis 2011), (Abednego 2011), (Rianto et al., 2018), (Albert Kurniawan Purnomo 2017), (Brian Permana Putra dan Mudiantono 2014). Badan Pusat Statistik perkembangan jumlah industri cafe dan restoran di Jawa Barat pada tahun 2013 sebanyak 2.714, terjadi penurunan dari tahun 2014 hingga 2015 menjadi 2.687 dan mengalami pertumbuhan yang cukup siginifikan ditahun 2016 hingga 2.853 cafe dan restoran di Jawa barat (Sumber: https://jabar.bps.go.id, 2018).

Semakin banyaknya pesaing cafe, membuat para pemain industri ini harus memperhatikan konsumen yang umumnya cepat berubah dan cenderung memperhatikan nilai-nilai kepuasan yang dirasakan oleh konsumennya. Perilaku masyarakat kota yang konsumtif, para pelaku bisnis berpartisipasi guna menjawab kebutuhan masyarakat akan permintaan yang diinginkan. Seiring dengan meningkatnya kecenderungan orang-orang untuk makan di cafe dan restoran atau sekedar berkumpul dengan teman-teman akan mendorong terjadinya pembelian ada yang terencana ada pula yang tidak terencana atau impulse buying.

Impulse buying (pembelian impulsif) merupakan suatu perilaku dimana konsumennya tidak merencanakan membeli satu produk/jasa dengan produk tertentu pada saat mereka berada dilingkungan toko atau cafe. Konsumen biasanya melakukan pembelian karena adanya rasa ketertarikan pada suatu produk tertentu. Rasa tertarik konsumen untuk membeli produk yang tidak direncanakan (impulse buying) pembelian yang terjadi di akibatkan adanya rangsangan tertentu. Impulse buying yaitu suatu kecenderungan konsumen untuk membeli produk secara spontan, tiba-tiba atau reflek. Impulse buying didefinisikan sebagai tindakan membeli yang sebelumnya tidak diakui secara sadar sebagai hasil dari suatu pertimbangan atau niat membeli yang terbentuk sebelum memasuki toko (Mowen \& Minor, 2002).

Dune and Lusch (2005) mengatakan bahwa impulse buying adalah pengaruh yang timbul dari stimuli-stimuli yang disebabkan oleh store environment yang 
konsumen rasakan, sehingga dalam penelitian ini emotional response di gunakan sebagai variabel antara. Secara spesifik, dokumentasi mengenai suasana sebuah lingkungan belanja serta lingkungan retail dapat mengubah emosi konsumen (Donovan and Rossiter, 1982)

Dunne dan Lusch (Raditya et. al, 2018) menyatakan :"store environment sebagai bangunan fisik toko yang tersusun dari beberapa elemen seperti musik, pencahayaan, bentuk toko, petunjuk yang mengarahkan pengunjung serta elemen sumber daya manusia”.Menurut Solomon (Raditya et. al, 2018), suasana hati atau emosi seseorang atau kondisi psikologi pada saat pembelian dapat memiliki dampak yang besar pada apa yang dia beli atau bagaimana ia menilai pembeliannya dan keputusan pembelian. Dua dimensi, yaitu Pleasure (Kesenangan) dan Arousal (Bergairah).

Cafe merupakan salah satu yang selalu memperhatikan masalah store environment dan perilaku konsumen yang ada didalam cafe. Sehingga tema yang diusulkan peneliti adalah Analisis Store Environment Dan Emosi Positif Terhadap Impulse Buying Pada Industri Cafe. Tujuan penelitian ini yaitu untuk mengetahui bagaimana pengaruh store environment dan emosi positif terhadap impulse buying pada industri cafe.

\section{KAJIAN TEORI}

\section{Store Environment}

Store environment merupakan unsur yang penting dalam retailing mengingat bahwa $70 \%$ dari pembelian ternyata merupakan impulse buying atau pembelian yang tidak direncanakan (Dunne \& Lusch, dalam Sinaga, Suharyono dan Kumadji, 2016). Lingkungan (Environment) ialah semua karakteristik fisik dan social dari dunia eksternal konsumen, termasuk di dalamnya objek fisik (produk dan cafe), hubungan keruangan (lokasi cafe dan produk di cafe), dan perilaku sosial orang lain (siapa yang berada di sekitar dan apa yang mereka lakukan).Menurut Simamora (Putra, 2014) Store environment dapat dibagi menjadi tiga bagian penting, yaitu :

1. Store Image. Store image merupakan salah satu alat yang terpenting bagi retailer untuk menarik dan memenuhi kepuasan konsumen. Konsumen menilai sebuah toko berdasarkan pengalaman mereka atas toko tersebut. Sebagai hasilnya beberapa toko akan menetap dalam benak konsumen apabila ia merasa puas 
akan toko tersebut sementara toko yang lain ia tidak akan pernah dipertimbangkan sama sekali. Walaupun begitu, menciptakan sebuah citra yang baik bagi konsumen adalah tugas yang tidak mudah. Citra adalah suatu banyangan atau gambaran yang ada di dalam benak seseorang yang timbul karena emosi dan reaksi terhadap lingkungan disekitarnya. Adapun citra konsumen terhadap sebuah toko terdiri dari kesan terhadap eksterior toko dan kesan terhadap interior toko.

2. Store Atmosphere. Untuk menciptakan atmosfer toko yang merangsang pembelian, sebuah retailer harus mempu membangkitkan niat atau keinginan untuk berbelanja dalam benak konsumen. Seseorang yang punya prinsip hemat pun akan lebih menyukai atmosfer toko yang dapat merangsangnya untuk berbelanja. Atmosfer toko adalah keseluruhan efek emosional yang diciptakan oleh atribut fisik toko. Pada umumnya, setiap orang akan lebih tertarik pada toko yang dapat menawarkan lingkungan berbelanja yang aman dan nyaman. Atmosfer berbelanja yang menyenangkan adalah atmosfer dengan atribut yang dapat menarik kelima indra manusia, penglihatan, pendengaran, penciuman, peraba, dan perasa.

3. Store Theatrics. Retailing bukan hanya sekadar menjual produk tetapi lebih merupakan suatu pameran atau pagelaran produk yang memicu konsumen untuk membeli produk yang dipamerkan. Store theatric dapat menjadi senjata yang ampuh bagi kebanyakan retailer untuk mendapatkan competitive advantage yang mampu membedakan antara satu retailer dengan yang lainnya.

\section{Emosi Positif}

Menurut Hawkins) mendefinisikan emosi sebagai "strong, relatively uncontrolled feeling that affect our behavior" (yaitu perasaan yang kuat dan relative tidak terkendalikan yang mempengaruhi perilaku kita).

Menurut Solomon (Raditya et. al, 2018), suasana hati atau emosi seseorang atau kondisi psikologi pada saat pembelian dapat memiliki dampak yang besar pada apa yang dia beli atau bagaimana ia menilai pembeliannya. Emosi diklasifikasikan menjadi dua dimensi ortogonal, yaitu positif dan negatif (Park et. al, 2005). Emosi positif dapat didatangkan dari sebelum terjadinya mood seseorang, kecondongan sifat afektif seseorang dan reaksi pada lingkungan yang mendukung seperti ketertarikan pada item barang ataupun adanya promosi penjualan. 
Menurut Solomon (Inggrid, Suharyono dan Srikandi, 2016) mengemukakan sebuah suasana hati konsumen dapat memiliki dampak besar pada keputusan pembelian. Dua dimensi, yaitu :

1. Pleasure (Kesenangan). Pleasure, mengacu pada tingkat dimana individu merasakan baik, penuh kegembiraan, bahagia yang berkaitan dengan situasi tersebut. Pleasure diukur dengan penilaian reaksi lisan ke lingkungan (bahagia sebagai lawan sedih, menyenangkan sebagai lawan tidak menyenangkan, puas sebagai lawan tidak puas, penuh harapan sebagai lawan berputus asa, dan santai sebagai lawan bosan). Konseptualisasi terhadap pleasure dikenal dengan pengertian lebih suka, kegemaran, perbuatan positif.

2. Arousal (Bergairah). Arousal, mengacu pada tingkat dimana seseorang merasakan siaga, digairahkan, atau berada dalam situasi aktif. Arousal secara lisan dianggap sebagai laporan responden, seperti pada saat dirangsang, ditentang, atau diperlonggar (bergairah sebagai lawan tenang, hiruk pikuk sebagai lawan sepi, gelisah/gugup sebagai lawan percaya diri). Pengukurannya menggunakan metode semantic differential, dan membatasi arousal sebagai sebuah keadaan perasaan yang secara langsung ditaksir oleh laporan verbal. Beberapa ukuran nonverbal telah diidentifikasi dapat dihubungkan dan sesungguhnya membatasi sebuah ukuran dari arousal dalam situasi sosial.

\section{Impulse Buying}

Menurut Rook dan Fisher (Permadi, 2016) mendefinisikan sifat impulse buying sebagai “a consumers' tendency to buy spontaneously, immediately and kinetically". Pembelian impulsif adalah pembelian yang terjadi ketika konsumen mengalami perasaan tiba-tiba, penuh kekuatan dan dorongan yang kuat untuk membeli sesuatu dengan segera. Engel (Septian et al., 2016) juga menyatakan impulse buying adalah suatu tindakan pembelian yang dibuat tanpa direncanakan sebelumnya atau keputusan pembelian dilakukan pada saat didalam toko.

Menurut Rook dan Fisher (Permadi, 2016), impulse buying terdiri dari karakteristik berikut : 
1. Spontanitas. Keadaan bahwa konsumen melakukan kegiatan belanja secara tidak terduga atau tidak direncanakan sebelumnya, hal tersebut biasanya disebabkan oleh respon konsumen ketika berada di dalam toko.

2. Kekuatan, kompulsi, dan intensitas. Adanya motivasi untuk mengesampingkan halhal lain dan bertindak seketika.

3. Kegairahan dan stimulasi. Dimana terjadi desakan mendadak untuk membeli sering disertai emosi yang dicirikan sebagai "menggairahkan", "menggetarkan" atau "liar".

4. Ketidakpedulian akan akibat. Desakan keinginan untuk membeli menjadi tidak dapat ditolak sehingga akibat yang mungkin negatif diabaikan.

\section{METODE PENELITIAN}

Penelitian ini dilaksanakan di CV. Bp Travel (Cafe Butler Bar \& Bistro) Kota Sukabumi. Menggunakan pendekatan manajemen pemasaran, yang khususnya membahas tentang Store Environment, Emosi Positif dan Impulse Buying. Populasi dalam penelitian ini adalah konsumen yang pernah berkunjung ke CV. Bp Travel (Cafe Butler Bar \& Bistro) Kota Sukabumi. Metode yang digunakan adalah menggunakan teknik probability sampling dengan metode pendekatan simple random sampling dan dengan melakukan penyebaran kuesioner sebanyak 100 kepada responden.Teknik analisis yang digunakan adalah uji validitas, uji reliabilitas, teknik analisis koefisien korelasi ganda, koefisien determinasi, regresi linear berganda, pengujian hipotesis menggunakan uji secara simultan (uji F), dan uji secara parsial (uji T).

\section{HASIL PENELITIAN}

Untuk melakukan teknik analisis, peneliti menggunakan bantuan perangkat lunak SPSS 24.

Tabel 1

Koefisien Korelasi antara Store Environment dan Emosi Positif

Terhadap Impulse Buying

Model Summary

\begin{tabular}{|l|l|r|r|r|}
\hline Model & R & R Square & \multicolumn{1}{c|}{$\begin{array}{c}\text { Adjusted R } \\
\text { Square }\end{array}$} & $\begin{array}{c}\text { Std. Error of } \\
\text { the Estimate }\end{array}$ \\
\hline 1 & $.661^{\mathrm{a}}$ & .437 & .425 & 3.892 \\
\hline
\end{tabular}

a. Predictors: (Constant), Emosi Positif, Store Environment 
Berdasarkan tabel 1 diatas diperoleh angka $\mathrm{R}$ sebesar 0,661 berada pada kategori 0,60-0,799. Hal ini menunjukan bahwa terjadinya hubungan yang kuat antara store environment dan emosi positif dengan impulse buying.

\section{Koefesien Determinasi}

Penghitungan koefisien determinasi ini dilakukan untuk mengetahui besarnya Store Environment dan Emosi Positif terhadap Impulse Buying, dapat dihitung dengan menggunakan rumus koefisien determinasi sebagai berikut:

$$
\mathrm{Kd}=\mathrm{r}^{2} \times 100 \%
$$

\section{Dimana:}

$\mathrm{Kd} \quad=$ Koefisien Determinasi

$\mathrm{r} \quad=$ Koefisien korelasi

Perhitungannya adalah sebagai berikut:

$$
\begin{aligned}
\mathrm{Kd} & =\mathrm{r}^{2} \times 100 \% \\
& =(0,661)^{2} \times 100 \% \\
& =0,437 \times 100 \% \\
& =43,7 \%
\end{aligned}
$$

Adapun kriteria untuk koefisien determinasi adalah sebagai berikut, jika "Kd" mendekati 0, maka pengaruh variabel $X_{1}$ dan $X_{2}$ terhadap variabel $Y$ lemah, jika "Kd" mendekati 1, maka pengaruh variabel $\mathrm{X}_{1}$ dan $\mathrm{X}_{2}$ terhadap variabel $\mathrm{Y}$ kuat. Berdasarkan perhitungan koefisien determinasi yang telah peneliti lakukan, diketahui bahwa nilai $\mathrm{Kd}$ $=43,7 \%$ sedangkan sisanya 56,3\% $(100 \%-43,7 \%=56,3 \%)$ dari faktor yang tidak diteliti. Maka dapat disimpulkan bahwa Store Environment dan Emosi Positif terhadap Impulse Buying yaitu lemah. 


\section{Regresi Linier Berganda}

Tabel 2

Hasil Perhitungan Regresi Linier Berganda

\begin{tabular}{|c|c|c|c|c|c|}
\hline \multicolumn{6}{|c|}{ Coefficients $^{\mathrm{a}}$} \\
\hline \multirow[b]{2}{*}{ Model } & \multicolumn{2}{|c|}{ Unstandardized Coefficients } & \multirow{2}{*}{$\begin{array}{c}\text { Standardized } \\
\text { Coefficients } \\
\text { Beta }\end{array}$} & \multirow[b]{2}{*}{$\mathrm{T}$} & \multirow[b]{2}{*}{ Sig. } \\
\hline & $\mathrm{B}$ & Std. Error & & & \\
\hline $\begin{array}{ll}1 & \text { (Constant) }\end{array}$ & 1.400 & 3.508 & & .399 & .691 \\
\hline Kualitas Makanan & .345 & .064 & .463 & 5.422 & .000 \\
\hline Perceived Value & .137 & .317 & .307 & 3.589 & .001 \\
\hline
\end{tabular}

Dari hasil output SPSS 24 di atas, dapat diketahui persamaan regresi ganda yaitu: $\quad a=1.400, b_{1}=0,345, b_{2}=0,137$. Selanjutnya didapat persamaan regresi linear berganda untuk dua predikator yaitu store environment dan emosi positif adalah sebagai berikut: $\mathrm{Y}^{*}=1.400+0,345 \mathrm{X}_{1}+0,137 \mathrm{X}_{2}$. Berdasarkan persamaan diatas, maka dapat diketahui terdapat pengaruh positif antara store environment $\left(\mathrm{X}_{1}\right)$ dan emosi positif $\left(\mathrm{X}_{2}\right)$ terhadap impulse buying (Y). Impulse buying akan meningkat, bila store environment $\left(\mathrm{X}_{1}\right)$ dan emosi positif $\left(\mathrm{X}_{2}\right)$ ditingkatkan. Adapun koefisien regresi untuk store environment sebesar 0,345 lebih besar dari pada koefisien regresi emosi positif sebesar 0,137 .

\section{Uji Secara Parsial T}

Untuk mengetahui hasil pengujian masing-masing variabel independen terhadap variabel dependen. Yang dimana terdiri variabel dependen terdiri dari store environment dan emosi positif, sedangkan variabel dependennya adalah impulse buying. Data yang digunakan untuk perhitungan uji t selanjutnya, dimasukan dan dihitung melalui perangkat lunak SPSS 24. Adapun hasil perhitungan tersebut adalah sebagai berikut.

Tabel 3

Hasil Pengujian Hipotesis (Uji T)

\begin{tabular}{|c|c|c|c|c|c|c|}
\hline \multirow{2}{*}{\multicolumn{2}{|c|}{ Model }} & \multicolumn{2}{|c|}{ Unstandardized Coefficients } & \multirow{2}{*}{$\begin{array}{c}\text { Standardized } \\
\text { Coefficients } \\
\text { Beta }\end{array}$} & \multirow{2}{*}{$\mathrm{T}$} & \multirow[b]{2}{*}{ Sig. } \\
\hline & & $\mathrm{B}$ & Std. Error & & & \\
\hline \multirow[t]{3}{*}{1} & (Constant) & 1.400 & 3.508 & & .399 & .691 \\
\hline & Kualitas Makanan & .345 & .064 & .463 & 5.422 & .000 \\
\hline & Perceived Value & .137 & .317 & .307 & 3.589 & .001 \\
\hline
\end{tabular}


Dapat ditarik kesimpulan bahwa variabel store environment dengan nilai sig. $0,000<0,10 t_{\text {hitung }} 5,442>1.66071 t_{\text {tabel }}$, artinya store environment berpengaruh positif dan signifikan secara parsial terhadap impulse buying. Maka $\mathrm{H}_{1}$ : Store Environment berpengaruh terhadap Impulse Buying Pada Konsumen Cafe Butler Bar \& Bistro Kota Sukabumi, diterima, hitung 3,589 > t tabel 1,66071

Selanjutnya untuk variabel emosi positif nilai nilai sig. $0,001<0,10$, nilai $t$ hitung 3,589 > $1.66071 \mathrm{t}$ tabel, artinya emosi positif berpengaruh positif dan signifikan secara parsial terhadap impulse buying. Maka $\mathrm{H}_{2}$ : Emosi Positif berpengaruh terhadap Impulse Buying Pada Konsumen Cafe Butler Bar \& Bistro Kota Sukabumi, diterima.

\section{Uji Secara Simultan (Uji F)}

Tabel 4

Hasil Pengujian Hipotesis (Uji T)

\begin{tabular}{|c|c|c|c|c|c|c|}
\hline \multicolumn{7}{|c|}{ ANOVA $^{a}$} \\
\hline \multicolumn{2}{|c|}{ Model } & Sum of Squares & Df & Mean Square & $\mathrm{F}$ & Sig. \\
\hline \multirow[t]{3}{*}{1} & Regression & 1141.170 & 2 & 570.585 & 37.661 & $.000^{\mathrm{b}}$ \\
\hline & Residual & 1469.590 & 97 & 15.150 & & \\
\hline & Total & 2610.760 & 99 & & & \\
\hline
\end{tabular}

Berdasarkan tabel di atas, didapatkan hasil $\mathrm{F}$ hitung variabel $\mathrm{X}_{1}$ (store environment), $\mathrm{X}_{2}$ (emosi positif) dan $\mathrm{Y}$ (impulse buying) adalah sebesar 37,661. Selanjutnya nilai $\mathrm{F}$ hitung tersebut dibandingkan dengan nilai $\mathrm{F}$ tabel. $\mathrm{F}$ tabel dicari pada tabel yang tertera pada lampiran dengan didasarkan pada $\mathrm{dk}$ pembilang $=\mathrm{k}$ dan $\mathrm{dk}$ penyebut $=(\mathrm{n}-\mathrm{k}-\mathrm{l})$ dan taraf kesalahan yang ditetapkan. Adapun taraf kesalahan yang ditetapkan adalah sebesar $10 \%$, jadi dk pembilang $=2$, dan $\mathrm{dk}$ penyebut $=97$, sehingga diperoleh nilai $\mathrm{F}$ tabel $=2,36$.

Hal tersebut dapat disimpulkan bahwa terdapat pengaruh yang signifikan antara variabel $\mathrm{X} 1, \mathrm{X} 2$ dan $\mathrm{Y}$. Adapun hasil pengujian hipotesisnya adalah sebagai berikut : F hitung $\geq \mathrm{F}$ table 37,661 > 2,36. Dari hasil uji f yang dilakukan, diperoleh nilai sig. $0,000<0,10$, nilai $37,661 \mathrm{~F}_{\text {hitung }}>\mathrm{F}_{\text {tabel }} 2,36$. Artinya bahwa store environment dan emosi positif secara bersama-sama (simultan) berpengaruh terhadap impulse 
buying. Maka $\mathrm{H}_{3}$ : Store Environment dan Emosi Positif Berpengaruh terhadap Impulse Buying, diterima.

\section{PEMBAHASAN}

\section{Store Environment berpengaruh terhadap Impulse Buying}

Hasil penelitian ini sama dengan penelitian (Permadi, 2016), dimana Store Environment berpengaruh positif dan signifikan terhadap Impulse Buying (Y) secara parsial hal ini dapat dibuktikan dari hasil pengujian uji t menunjukkan nilai sig. $0,000<$ 0,10 $\mathrm{t}_{\text {hitung }} 5,442>1.66071 \mathrm{t}_{\text {tabel, }}$ maka dapat disimpulkan bahwa Ho ditolak dan Ha diterima. Maka menunjukkan bahwa Store Environment memberikan nilai positif dalam mempengaruhi impulse buying pada perusahaan.

Adapun hubungan Store Environment terhadap Impulse Buying menurut Fitriani (2010) bahwa lingkungan toko atau store environment mempunyai pengaruh positif terhadap impulse buying. Penelitian ini juga didukung dengan hasil penelitian yang telah dilakukan oleh Jondry Adrin Hetharie (Permadi, 2016) bahwa stimulus berupa musik, warna, aroma, dan ketersediaan produk yang diberikan oleh pihak Matahari Departement Store kota Ambon berdampak pada minat konsumsi dan impulse buying tendency. Yang artinya hasil dari penelitian ini bahwa Store Environment memberikan nilai positif dalam mempengaruhi impulse buying, karna lingkungan yang dirasakan konsumen mendorong terjadinya pembeliam impulse buying atau pembelian yang tidak terencana.

\section{Emosi Positif Berpengaruh Terhadap Impulse Buying}

Hasil penelitian ini sama dengan penelitian Putra (2014), dimana Emosi Positif berpengaruh positif dan signifikan terhadap Impulse buying (Y) secara parsial. Hal ini dapat dibuktikan dari hasil pengujian uji t menunjukkan nilai sig. $0,001<0,10$, nilai $\mathrm{t}$ hitung $3,589>1.66071 \mathrm{t}_{\text {tabel }}$, artinya emosi positif berpengaruh positif dan signifikan secara parsial terhadap impulse buying pada perusahaan.

Menciptakan emosi positif konsumen terhadap kenyamanan saat berada didalam café adalah yang penting dilakukan. Emosi yang positif merupakan salah satu alasan konsumen mau membeli atau menggunakan suatu produk/jasa yang ada di dalam cafe. 


\section{Store Environment dan Emosi Positif Berpengaruh terhadap Impulse Buying}

Berdasarkan pada hasil hitungan penelitian analisis regresi berganda uji $\mathrm{F}$ dengan tingkat signifikan sebesar 0,10 (10\%) menunjukan bahwa variabel Store Environment $\left(\mathrm{X}_{1}\right)$ dan Emosi Positif $\left(\mathrm{X}_{2}\right)$ berpengaruh secara bersama-sama terhadap Impulse Buying (Y). Hal ini ditunjukan dengan hasil nilai sig. $0,000<0,10$; nilai $\mathrm{F}_{\text {hitung }}$ $37.661>\mathrm{F}_{\text {tabel }}$ 2.36. Nilai Koefisien Determinasi $\left(\mathrm{R}^{2}\right)$ diperoleh hasil dari variabel Store Environment $\left(\mathrm{X}_{1}\right)$ dan Emosi Positif $\left(\mathrm{X}_{2}\right)$ mempengaruhi sebesar 42,5\% $(0,425)$ terhadap Impulse Buying (Y), sisanya 57,5\% dipengaruhi oleh faktor-faktor lain diluar penelitian ini. Hal ini dikarenakan suatu Store Environment dan Emosi Positif berperan penting dalam mendorong konsumen melakukan Impulse Buying. Dengan demikian dapat diketahui bahwa Store Environment $\left(\mathrm{X}_{1}\right)$ dan Emosi Positif $\left(\mathrm{X}_{2}\right)$ merupakan faktor yang membentuk Impulse Buying (Y) Pada Konsumen Cafe Butler Bar \& Bistro Kota Sukabumi secara simultan.

\section{SIMPULAN}

Secara parsial, store environment berpengaruh dan signifikan terhadap impulse buying pada konsumen Cafe Butler Bar \& Bistro Kota Sukabumi. Secara parsial, emosi positif berpengaruh dan signifikan terhadap impulse buying pada konsumen Cafe Butler Bar \& Bistro Kota Sukabumi. Secara simultan, Store environment dan emosi positif berpengaruh positif dan signifikan terhadap impulse buying pada konsumen Cafe Butler Bar \& Bistro Kota Sukabumi.

\section{DAFTAR PUSTAKA}

Abednego, Felicia. (2011). Analisis Pengaruh Atmosfer Gerai Terhadap Penciptaan Emosi (Arousal Dan Pleasure), Perilaku Belanja (Motivasi Belanja Hedonik Dan Motivasi Belanja Utilitarian), Dan Terhadap Pendekatan Perilaku. Fokus Ekonomi (FE). 10(2). 125-139.

Badan Pusat Statistik. (2017). Perkembangan Jumlah Industri Café dan Restoran Di Jawa Barat, [Online]. Tersedia: https://jabar.bps.go.id, [November 2018].

Dunne, P. M and Lusch, R. F. (2005). Retailing (55th Ed.). Ohio: South Western, A Division of Thomson Learning

Donovan, Robert J., Rossiter, John R,. Marcoolyn, Gillian, and Andrew Nesdale. (1994). "Store Atmosphere and Purchasing Behaviour". Journal of Retailing. 70(3), 283-294.

Fitriani, Rahma. (2010). "Studi Tentang Impulse Buying Pada Hypermarket di Kota Semarang”. Fakultas Ekonomi Universitas Diponogoro, Semarang. 
Kharis, Ismu Fadli. (2011). Studi Mengenai Impulse Buying dalam Penjualan Online. Skripsi Universitas Diponegoro. Semarang.

Mowen, John C., dan Michael Minnor. (2002). Perilaku Konsumen. Alih Bahasa: Dwi Kartini Yahya. Jilid 2. Jakarta: Penerbit Erlangga.

Raditya Kirana Rianto, Suharyono, Aniesa Samira Bafadhal. (2018). Pengaruh Store Environment Terhadap Shopping Emotion Dan Impulse Buying (Studi Pada Konsumen Vargo Kitchen Malang) . Jurnal Administrasi Bisnis, 59(1), 40-50

Rianto, R. K., Suharyono., Bafadhal, A. S. (2018). Pengaruh Store Environment Terhadap Shopping Emotion Dan Impulse Buying (Studi Pada Konsumen Vargo Kitchen Malang) . Jurnal Administrasi Bisnis, 59(2),60-71

Park, E. J., Kim, Eun Yong, and Forney, J.C. (2005). A Structural Model Of Fashion Oriented Impulse Buying Behavior. Jurnal Of Fashion Marketing And Manajement, 10(4), 433-446.

Permadi, D. E. (2016). Pengaruh Stimulus Lingkungan dan Lifestyle Terhadap Impulse Buying (Study Terhadap Konsumen di Matahari Departement Store, Central Plaza Bandar Lampung). Skripsi

Putra, B. P. (2014). Analisis Pengaruh Promosi, Emosi Positif Dan Store Environment Terhadap Impulse Buying (Studi Kasus Pada Pelanggan Swalayan Tong Hien Di Kota Semarang). Skripsi.

Septian, V.T, Fauzi, A., Mawardi, M. K. (2016). Pengaruh Store Atmosphere (Suasana Toko) Terhadap Emosi Serta Dampaknya Pada Keputusan Pembelian (Survei pada Pembeli di Ria Djenaka Cafe dan Resto, Kota Batu). Jurnal Administrasi Bisnis, 30(1), 56-76

Sinaga, I., Suharyono, Kumadji, S. (2016). Stimulus Store Environment Dalam Menciptakan Emotional Response Dan Pengaruhnya Terhadap Impulse Buying (Survei pada Pembeli di Carrefour Mitra I Malang) . Jurnal Profit , 6(2), 60-70 